\title{
Sistem Pendukung Keputusan Pengangkatan Jabatan Pimpinan Tinggi Pratama Dengan Metode Simple Additive Weighting
}

\author{
Nina Karina Lolo Bintang ${ }^{1 *}$, Bosker Sinaga ${ }^{2}$ \\ ${ }^{1,2}$ STMIK Pelita Nusantara \\ Jl. Iskandar Muda No. 1 Medan 20154 Indonesia \\ Corresponding author's e-mail: ninakaelbintang90@gmail.com
}

\begin{abstract}
Abstrak - Proses rekrutmen masih memanfatakan prinsip konvensional dalam pengolahan data sehingga memungkinkan terjadinya perubahan angka-angka ataupun nilai masing-masing calon dan tentunya ada pihak yang dirugikan, dalam proses pengolahan data membutuhkan waktu yang lama. Temuan yang lainnya adalah terjadinya penumpukan berkas karena syarat adminsitrasi membutuhkan berkas-berkas dari para calon yang mendaftar. Data diperoleh dari BKD (Badan Kepegawaian Daerah) Kabupaten Karo. Kriteria Berdasarkan Peraturan Daerah Kabupaten Karo yaitu Tes Kompetensi, Uji Gagasan Tertulis, Uji Gagasan Lisan, Rekam Jejak. Dengan bantuan perangkat lunak brainware dapat membangun sistem melalui Bahasa pemrograman. Pada Aplikasi Sistem Pendukung Keputusan ini Perangkat lunak yang digunakan untuk membangun sistem Pendukung Keputusan dengan Menggunakan Metode SAW (Simple Addictive Weighting). Aplikasi yang dikembangkan berbasis web dengan menggunakan PHP dan Mysql. Nilai terbesar ada pada V1 dan V3 sehingga alternatif V1 dan V3 adalah alternatif yang direkomendasikan oleh Sistem dengan nilai yang sama yaitu 1.
\end{abstract}

Kata kunci: rekrutmen, kriteria, perangkingan, $S P K, S A W$

Abstract - The recruitment process still utilizes conventional principles in data processing so as to allow changes in the numbers or values of each candidate and of course there are parties who are disadvantaged, in the data processing process it takes a long time. Another finding is the accumulation of files because the administrative requirements require documents from the registering candidates. Data obtained from BKD (Regional Civil Service Agency) Karo Regency. The criteria based on the Karo Regency Regional Regulation are Competency Test, Written Idea Test, Oral Idea Test, Track Record. Decision Support Using the SAW (Simple Addictive Weighting) Method. The application is developed based on web using PHP and Mysql. The biggest values are in V1 and V3 so that the alternatives V1 and V3 are the alternatives recommended by the system with the same value, namely 1 .

Keywords: recruitment, criteria, ranking, SPK, SAW

\section{Pendahuluan}

Kemajuan teknologi yang sangat pesat saat ini sangat dirasakan oleh badan-badan organisasi yang banyak menghasilkan dan membutuhkan informasi dalam kegiatan operasionalnya, karena disadari bahwa komputer merupakan alat bantu untuk menyelesaikan berbagai pekerjaan manusia secara cepat dan tepat. Disamping itu komputer juga dapat menyimpan data, memperbaiki data, serta mengambil informasi yang diinginkan, dimana data dan informasi tersebut disimpan dalam suatu media penyimpanan berupa file [1]. Demikian halnya pemerintahan telah menggunakan komputer sebagai bagian yang tidak terpisahkan dalam menunjuang kinerja dari masing-masing, salah satunya adalah Kabupaten Karo yang setiap harinya terus berkembang dalam pemanfaatan teknologi komputer. Namun beberapa kegiatan untuk penentuan jabatan pada Unit tertentu masih tetap konvensional seperti halnya Penentuan Jabatan Pimpinan Tinggi Pratama. Jabatan Pimpinan Tinggi Pratama dalam suatu institusi pemerintahan merupakan suatu jabatan pada bidang-bidang tertentu untuk melakukan kegiatan, merumuskan kebijakan dan rencana strategis sesuai visi, misi, dan program, memimpin, mengkoordinasikan, membina, mengawasi dan mengendalikan serta mengevaluasi pelaksanaan tugas dan fungsi bidang dan melaksanakan tugas kedinasan lain yang diberikan oleh pimpinan sesuai tugas dan fungsi jabatan, Demikian halnya pada BKD (Badan Kepegawaian Daerah ) membutuhkan sosok pimpinan yang mumpuni untuk mengembangkan BKD Kabupaten Karo. Proses Rekrutmen jabatan Pimpinan Tinggi Pratama pada BKD dilakukan secara terbuka dengan membentuk panitia seleksi dengan tanggung jawab penuh mulai dari proses administrasi para calon, pelaksanan ujian dan penentuan nilai yang diperoleh. Untuk menyelesaikan permasalah tersebut dan untuk mempermudah proses penyelesaian maka dikembangkan aplikasi berbasis web yang dapat menampung dan mengelola berkas yang masuk dari para calon, sedangkan untuk membantu proses perhitungan dilibatkan suatu metode yaitu SAW (Simple Addictive Weighting) [2]. Metode SAW dapat membantu dalam pengambilan keputusan suatu kasus, akan tetapi perhitungan dengan menggunakan metode 
SAW ini hanya yang menghasilkan nilai terbesar yang akan terpilih sebagai alternatif yang terbaik. Perhitungan akan sesuai dengan metode ini apabila alternatif yang terpilih memenuhi kriteria yang telah ditentukan. Metode SAW ini lebih efisien karena waktu yang dibutuhkan dalam perhitungan lebih singkat. Metode SAW membutuhkan proses normalisasi matriks keputusan (X) ke suatu skala yang dapat diperbandingkan dengan semua rating alternatif yang ada [3].

Penelitian SPK Penentuan Pemberian Pinjaman Kepada Anggota Bumdes Dengan Metode Simple Additive Weighting menjelaskan penerapan Sistem Pendukung Keputusan dengan Metode Simple Additive Weighting dapat dipergunakan untuk penentuan pemberian pinjaman kepada anggota BUMDes Maju Bersama dengan memasukan berupa data alternatif kemudian memasukan nilai bobot yang dilihat pada kriteria yang ada, sehingga dapat menghasilkan nilai perhitungan dan perengkingan nama calon nama penerima pinjaman. rancangan ini akan menampilkan hasil akhir dari setiap anggota yang akan meminjam dana, dan rating tertinggi bisa dikatakan anggota yang akan menerima bantuan pinjaman, Rating terendah akan diberi kesempatan dalam pengambilan keputsan nantinya untuk menerima bantuan pinjaman [4].

\section{Tinjauan Pustaka}

2.1. Sistem Pendukung Keputusan (SPK)

Sistem tersebut adalah suatu sistem yang berbasis komputer yang ditujukan untuk membantu mengambil keputusan dengan memanfaatkan data dan model tertentu untuk memecahkan berbagai persoalan yang tidak terstruktur. SPK adalah sebuah sistem yang mampu memberikan kemampuan pemecahan masalah maupun kemampuan pengkomunikasian untuk masalah dengan kondisi semi terstruktur dan tak terstruktur[5]. Sistem ini digunakan untuk membantu pengambilan keputusan dalam situasi semi terstruktur dan situasi yang tidak terstruktur, tak seorang pun tahu secara pasti bagaimana keputusan seharusnya dibuat. Sub Sistem Manajemen Basis Data (Database Management Subsystem) Suatu sub-sistem yang memanajemen data dengan memasukkan satu database yang berisi data yang relevan dan dikelola oleh perangkat lunak [6] [7].

1. Sub Sistem Manajemen Basis Model (Model Base Management Subsystem) Sub Sistem ini mengatur semua permasalahan integrasi akses data dan model keputusan yang ada dalam sebuah Sistem Pendukung Keputusan.

2. Sub Sistem Perangkat Lunak Penyelenggara Dialog (Dialog Generation and Management Software).

3. Sub sistem ini mencakup semua hubungan yang terjadi antara Sistem Pendukung Keputusan dan Pengguna.

2.2 Metode Simple Addictive Weighting (SAW)

Metode SAW dikenal dengan istilah metode penjumlahan berbobot. Konsep dasar metode Simple Addictive Weighting adalah mencari penjumlahan terbobot dari rating kinerja pada setiap alternatif pada semua atribut. SAW disarankan untuk menyelesaikan masalah penyeleksian dalam sistem pengambilan keputusan multi proses [8]. Metode Simple Addictive Weighting merupakan metode yang banyak digunakan dalam pengambilan keputusan yang memiliki banyak atribut. Metode Simple Addictive Weighting membutuhkan proses normalisasi matriks keputusan. Dalam penelitihan ini mengggunakan metode SAW (Simple Addictive Weighting). Adapun langkah-langkahnya adalah [9] [10] :

1. Menentukan kriteria-kriteria yang akan dijadikan acuan dalam pengambilan keputusan, yaitu Ci.

2. Menentukan rating kecocokan setiap alternatif pada setiap kriteria.

3. Membuat matriks keputusan berdasarkan kriteria (Ci), kemudian melakukan normalisasi matriks berdasarkan persamaan yang disesuaikan dengan jenis atribut (atribut keuntungan ataupun atribut biaya) sehingga diperoleh matriks ternormalisasi R.

4. Hasil akhir diperoleh dari proses perankingan yaitu penjumlahan dari perkalian matriks ternormalisasi $\mathrm{R}$ dengan vektor bobot sehingga diperoleh nilai terbesar yang dipilih sebagai alternatif terbaik (Ai) sebagai solusi.

\section{Metode Penelitian}

Uraian kerangka penelitian:

1. Identifikasi Masalah. Pada tahapan ini peneliti memastikan apa yang menjadi permasalahan pada objek yang diteliti yaitu BKD (Badan Kepagawaian Daerah) tentang Penentuan Pimpinan Tinggi Pratama.

2. Penentuan Permasalahan. Dari identifikasi masalah pada langkah pertama akan dilanjutkan terhadap tahapan penentuan permasalahan. Pada penelitian ini, yang menjadi masalah adalah Penentuan Pimpinan Tinggi Pratama masih secara konvensional yang hanya melibatkan teknologi komputer untuk pengumuman, sedangkan dalam pengolahan data masih dengan perhitungan manual.

3. Pengumpulan Data. Pada tahapan ini penulis akan mengumpulkan data yang berhubungan dengan 
Penentuan Pimpinan Tinggi Pratama dengan beberapa tahapan yaitu Studi Pustaka, Observasi dan Wawancara.

a. Studi Pustaka. Penulis memperoleh data-data dengan cara mengutip dari beberapa bahan bacaan untuk memperoleh data dan informasi yang sifatnya teoritis yang dapat membantu penulis dalam menyelesaikan skripsi ini, penulis juga menggunakan buku-buku sebagai dasar pengetahuan penulis.

b. Observasi. aktifitas terhadap suatu proses atau objek dengan cara mengamati secara langsung terhadap Panitia yang melakukan Penentuan Pimpinan Tinggi Pratama untuk mendapatkan informasi yang jelas dan benar.

c. Wawancara. Adalah proses komunikasi lisan yang bertujuan menggali informasi tertentu dengan cara terstruktur dan dilakukan dua orang atau lebih. Dengan cara wawancara dan terjun langsung melakukan tanya jawab kepada ketua Panitia Penentuan Pimpinan Tinggi Pratama pada BKD Kabupaten Karo.

4. Penerapan Metode SAW. Data yang sudah pada tahapan pengumpulan data akan dilanjutkan pada pengujian dengan menggunakan Metode SAW, dimana metode ini merupakan salah satu metode yang dapat digunakan untuk melakukan rekomendasi terhadap suatu keputusan tertentu.

5. Perancangan. Bagian ini proses perancangan mulai dari pembentukan UML (Unified Modelling Language) untuk menggambarkan alur perancangannya, selanjutnya perancangan antar muka sebagai bagian dari pengembangan aplikasi dan dilanjutkan dengan perancangan basis data.

6. Kode Program. Kode program merupakan tahapan pembuatan aplikasi, pada penelitian ini yang akan dikembangkan adalah aplikasi dalam Penentuan Pimpinan Tinggi Pratama berbasis web.

7. Pengujian. Tahapan pengujian merupakan tahapan output dari analisa dan perancangan yang telah dilakukan.

8. Implementasi. Implementasi merupakan sebagai tahapan akhir yaitu penggunaan aplikasi yang sudah dikembangkan sebagai rekomendasi Penentuan Pimpinan Tinggi Pratama.

\section{Hasil dan Pembahasan}

Berdasarkan identifikasi permasalahan maka diusulkan sistem yang dapat membantu permasalahan dalam proses penentuan Jabatan Pimpinan Tinggi Pratama.

1. Analisis Input

Analisis kebutuhan input yang digunakan dalam implementasi pada perhitungan Simple Addictive Weighting adalah data yang berhubungan dengan penempatan Pejabat Tinggi pratama yaitu kriteria-kriteria pendukung dan juga persentasi untuk masing-masing kriteria.

2. Analisis Proses

Analisis kebutuhan proses yang berupa pemodelan data. Analisis ini dimaksudkan untuk menggambarkan proses - proses yang terdapat di dalam program aplikasi melalui sebuah pemodelan. Pemodelan yang digunakan oleh penulis adalah pendekatan terstruktur dengan pemakaian UML (Unified Modeling Language) yang juga telah dijelaskan pada landasan teori.

3. Analisis Output

Analisis kebutuhan keluaran berupa tampilan program aplikasi yang akan dirancang pada perancangan antarmuka. Perancangan antarmuka program aplikasi ini menggunakan perangkat lunak pendukung.

1. Data Kriteria

Kriteria yang digunakan dalam proses penentuan jabatan dengan beberapa kriteria berikut ini :

1) Tes Kompetensi (TK)

Penilaian Tes Kompetensi Manajerial dan Sosial Kultural dengan metode Assessment center dilakukan oleh Lembaga Asesment untuk melakukan penilaian terhadap semua peserta yang dinyatakan lulus Tahap Seleksi Administrasi.

2) Uji Gagasan Tertulis (penulisan makalah) (UGT)

Panitia Seleksi melakukan penilaian kompetensi teknis setiap peserta dalam penulisan makalah sesuai dengan bidang tugas Jabatan Pimpinan Tinggi Pratama yang dilamar (program kegiatan inovatif dan visioner)

3) Uji Gagasan Lisan (presentasi dan wawancara) (UGL)

Panitia menunjuk tim untuk melakukan penilaian terhadap peserta untuk menilai gagasan yang akan diambil berdasarkan bidang tugas yang dilamar.

4) Penelusuran Rekam Jejak Peserta Seleksi (PRJ)

Pada bagian ini dilakukan peninjauan terhadap Rekam jejak Peserta dalam dalam meningkatkan Unit dilingkungan kerja masing-masing.

2. Data Alternatif 
Alternatif yang dijadikan Dalam menentukan Pegawai Negeri Sipil Dalam Jabatan Pimpinan Tinggi Pratama sebagai data uji adalah data peserta yang telah mendaftar dan hendak masuk ketahapan penilaian.

Model SAW dalam prosesnya memerlukan kriteria yang akan dijadikan bahan perhitungan pada proses perankingan. Kriteria yang menjadi bahan pertimbangan bagian proses penentuan Jabatan Pimpinan Tinggi Pratama C1=Tes Kompetensi C2 = Uji Gagasan Tertulis C3 = Uji Gagasan Lisan C4 = Penelusuran Rekam Jejak. Dari masing-masing kriteria ditentukan bobot persentasi setiap kriteria dengan uraian Tes kompetensi: 20\%, Uji Gagasan Tertulis: 20\%, Uji Gagasan Lisan: 30\%. Penelusuran Rekam Jejak: 30\%. Setelah proses pendefenisian alternatif dan kriteria maka dilanjutkan dengan proses perhitungan.

Langkah penyelesaian dalam penerapan metode Simple Addictive Weighting (SAW) meliputi :

1. Memberikan nilai setiap alternatif $(\mathrm{Ai})$ pada setiap kriteria $(\mathrm{Cj})$ yang sudah ditentukan. Hasil dapat dikonversikan ke bilangan crisp. Menentukan Rating Kecocokan.

2. Rating kecokan dengan penyesuaian antara data uji dengan nilai crips yang sudah diuraikan pada langkah 1 .

$$
X=\left[\begin{array}{cccc}
1 & 1 & 1 & 0.86 \\
1 & 1 & 1 & 0.71 \\
1 & 1 & 1 & 0.86 \\
1 & 0.86 & 1 & 0.71
\end{array}\right]
$$

3. Menentukan Nilai Bobot (W). Untuk menentukan bobot dari dalam penentuan Jabatan Pimpinan Tinggi Pratama.

4. Menormalisasi matriks X menjadi matriks $\mathrm{R}$ berdasarkan persamaan 1.

$$
r_{i j}=\left\{\begin{array}{l}
\frac{x_{i j}}{\operatorname{Max}_{i} X_{i j}} \text { Jika } \mathrm{j} \text { adalah atribut diterima } \\
\frac{\operatorname{Min}_{i} X_{i j}}{X_{i j}} \text { Jika i adalah atribut ditolak }
\end{array}\right.
$$

a. Tes Kompetensi

Untuk Tes Kompetensi termasuk ke dalam atribut keuntungan (benefit), karena semakin tinggi nilai maka dianggap semakin baik sehingga proses perhitungan dengan prinsip atribut diterima.

$$
\begin{aligned}
& r 1,1=\frac{1}{\operatorname{Max}\{1 ; 1 ; 1 ; 1\}}=\frac{1}{1}=1 ; r 1,2=\frac{1}{\operatorname{Max}\{1 ; 1 ; 1 ; 1\}}=\frac{1}{1}=1 \\
& r 1,3=\frac{1}{\operatorname{Max}\{1 ; 1 ; 1 ; 1\}}=\frac{1}{1}=1 ; r 1,4=\frac{1}{\operatorname{Max}\{1 ; 1 ; 1 ; 1\}}=\frac{1}{1}=1
\end{aligned}
$$

b. Uji Gagasan Tertulis

Uji Gagasan Tertulis termasuk ke dalam atribut keuntungan (benefit), karena semakin tinggi nilai maka dianggap semakin baik sehingga proses perhitungan dengan prinsip atribut diterima.

$$
\begin{aligned}
& r 2,1=\frac{1}{\operatorname{Max}\{1 ; 1 ; 1 ; 0.86\}}=\frac{1}{1}=1 ; r 2,2=\frac{1}{\operatorname{Max}\{1 ; 1 ; 1 ; 0.86\}}=\frac{1}{1}=1 \\
& r 2,3=\frac{1}{\operatorname{Max}\{1 ; 1 ; 1 ; 0.86\}}=\frac{1}{1}=1 ; r 2,4=\frac{0.86}{\operatorname{Max}\{1 ; 1 ; 1 ; 0.86\}}=\frac{0.86}{1}=0.86
\end{aligned}
$$

c. Uji Gagasan Tertulis

Uji Gagasan Tertulis termasuk ke dalam atribut keuntungan (benefit), sehingga perhitungan sebagai berikut :

$$
\begin{aligned}
& r 3,1=\frac{1}{\operatorname{Max}\{1 ; 1 ; 1 ; 1\}}=\frac{1}{1}=1 ; r 3,2=\frac{1}{\operatorname{Max}\{1 ; 1 ; 1 ; 1\}}=\frac{1}{1}=1 \\
& r 3,3=\frac{1}{\operatorname{Max}\{1 ; 1 ; 1 ; 1\}}=\frac{1}{1}=1 ; r 4,4=\frac{1}{\operatorname{Max}\{1 ; 1 ; 1 ; 1\}}=\frac{1}{1}=1
\end{aligned}
$$

d. Penelusuran Rekam Jejak

Uji Penelusuran termasuk ke dalam atribut keuntungan (benefit), sehingga perhitungan sebagai berikut : 


$$
\begin{aligned}
r 4,1 & =\frac{0.86}{\operatorname{Max}\{0.86 ; 0.71 ; 0.86 ; 0.71\}}=\frac{0.86}{0.86}=1 . \\
\frac{0.71}{0.86} & =0.82 \\
r 4,3 & =\frac{0.86}{\operatorname{Max}\{0.86 ; 0.71 ; 0.86 ; 0.71\}}=\frac{0.86}{0.86}=1 . \quad r 4,4=\frac{0.71}{\operatorname{Max}\{0.86 ; 0.71 ; 0.86 ; 0.71\}}= \\
\frac{0.71}{0.86} & =0.82
\end{aligned}
$$

Dari perhitungan diatas terbentuk matriks normalisasi R berikut ini :

$$
R=\left[\begin{array}{ccccc}
1 & 1 & 1 & 1 \\
1 & 1 & 1 & 0.86 \\
1 & 1 & 1 & 1 \\
1 & 0.82 & 1 & 0.82
\end{array}\right]
$$

5. Menghitung Nilai Preferensi (Vi) dengan rumus berikut ini :

$$
\mathrm{V}_{\mathrm{i}}=\sum_{\mathrm{j}=1}^{\mathrm{n}} \mathrm{W}_{\mathrm{j}} \mathrm{r}_{\mathrm{i} j}
$$

dan nilai bobot $\mathrm{W}=\left[\begin{array}{l}0.2 \\ 0.2\end{array}\right.$ 0.3 0.3]. Untuk Mendapatkan Preferensi Bobot $\left(\mathrm{W}_{\mathrm{kolom}}\right) \mathrm{X}$ Normalisasi

$\left(\mathrm{R}_{\text {baris,kolom }}\right)$

$\mathbf{V}_{1}=(1 \times 0.2)+(1 \times 0.2)+(1 \times 0.3)+(1 \times 0.3)=0.2+0.2+0.3+0.3=1$

$\mathrm{V} 2=(1 \times 0.2)+(1 \times 0.2)+(1 \times 0.3)+(0.86 \times 0,3)=0.2+0.2+0.3+0.25=0.95$

$\mathrm{V}_{3}=(1 \times 0.2)+(1 \times 0.2)+(1 \times 0.3)+(1 \times 0.3)=0.2+0.2+0.3+0.3=1$

$\mathrm{V} 4=(1 \times 0.2)+(0.82 \times 02)+(1 \times 0.3)+(0.82 \times 0,3)=0.2+0.16+0.3+0.24=0.90$

Fungsionalitas sistem aplikasi yang dirancang akan digambarkan dalam bentuk use case diagram. Use case diagram proses pengolahan data Sistem Pendukung Keputusan dapat dilihat pada gambar 1.

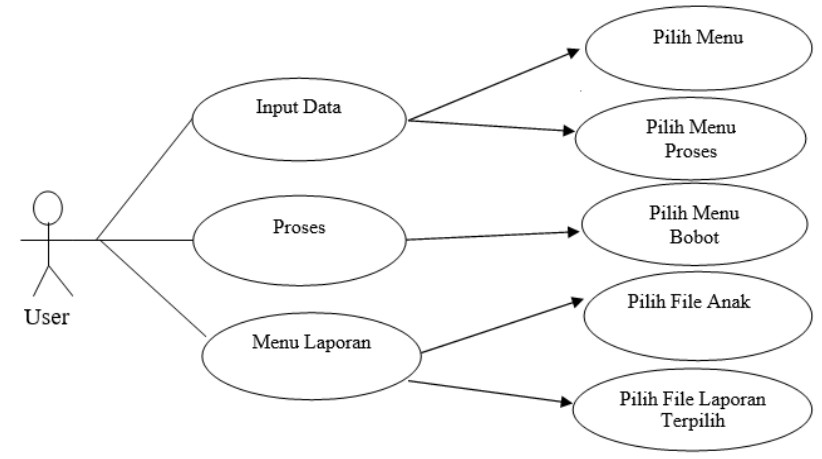

Gambar 1. Use Case

Tampilan Menu Utama Admin, Menu utama admin adalah fasilitas yang dapat digunakan oleh untuk melakukan input data yang dibutuhkan dalam Pengangkatan Pegawai Negeri Sipil Dalam Jabatan Pimpinan Tinggi Pratama, dengan beberapa menu yaitu halaman depan, data kriteria, data subkriteria, data alternatif, hasil seleksi, ubah password serta logout. 


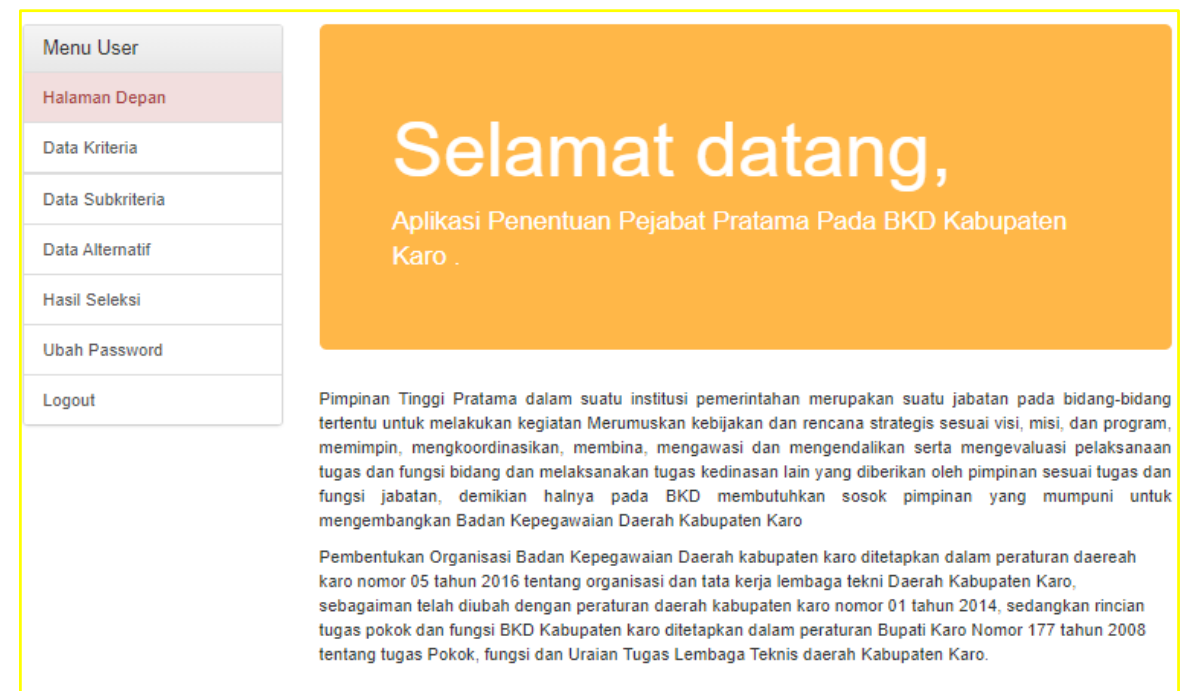

Gambar 2. Menu Utama Admin

Tampilan Data Kriteria, tampilan data kriteria merupakan implementasi untuk menampilkan keseluruhan data kriteria dengan beberapa kontrol tambahan yaitu input data digunakan untuk menambahkan kriteria baru,sedangkan tombol kontrol edit untuk melakukan perubahan data serta tombol hapus untuk menghapus data dari list. Tampilan data alternatif. Pada implemetnasi data alternatif merupakan fasilitas yang digunakan untuk penginputan alternatif yang digunakan sebagai bagian sistem pendukung keputusan dengan beberapa kontrol yaitu edit dan hapus serta input baru digunakan untuk menambahkan data alternatif dengan nilai-nilai yang dihasilkan pada saat dilakukan tes

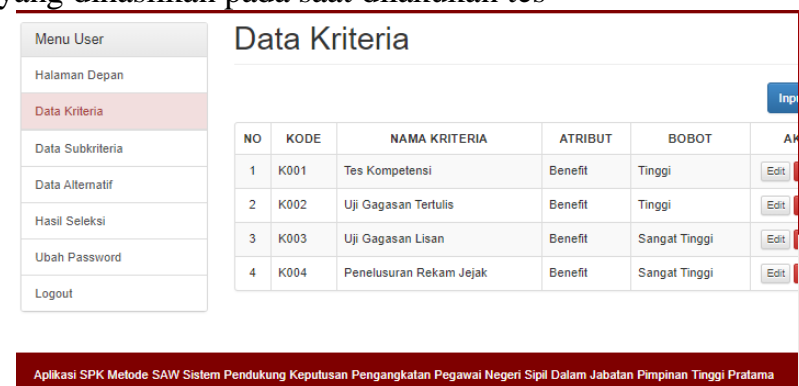

Gambar 3. Tampilan Data Kriteria

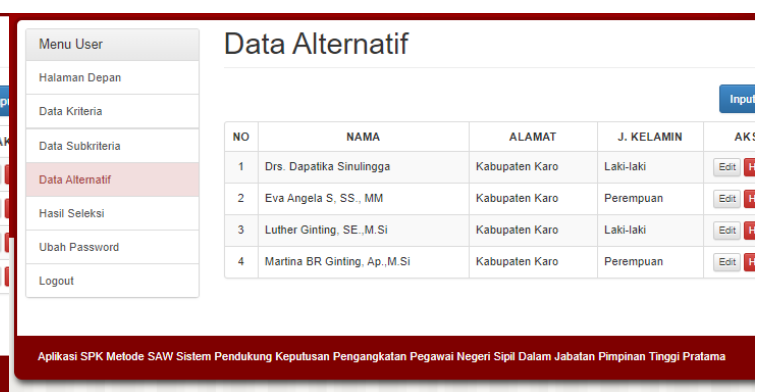

Gambar 4. Tampilan Data Alternatif

Hasil seleksi, implementasi hasil seleksi merupakan bagian penting dalam pengembangan sistem pendukung keputusan dengan beberapa item penting, yaitu menampilkan nilai alternatif yang dilengkapi dengan nilai setiap alternatif, selanjutnya tampil konversi nilai untuk masing-masing kriteria serta transformasi dilanjutkan dengan hasil akhir yaitu perankingan.

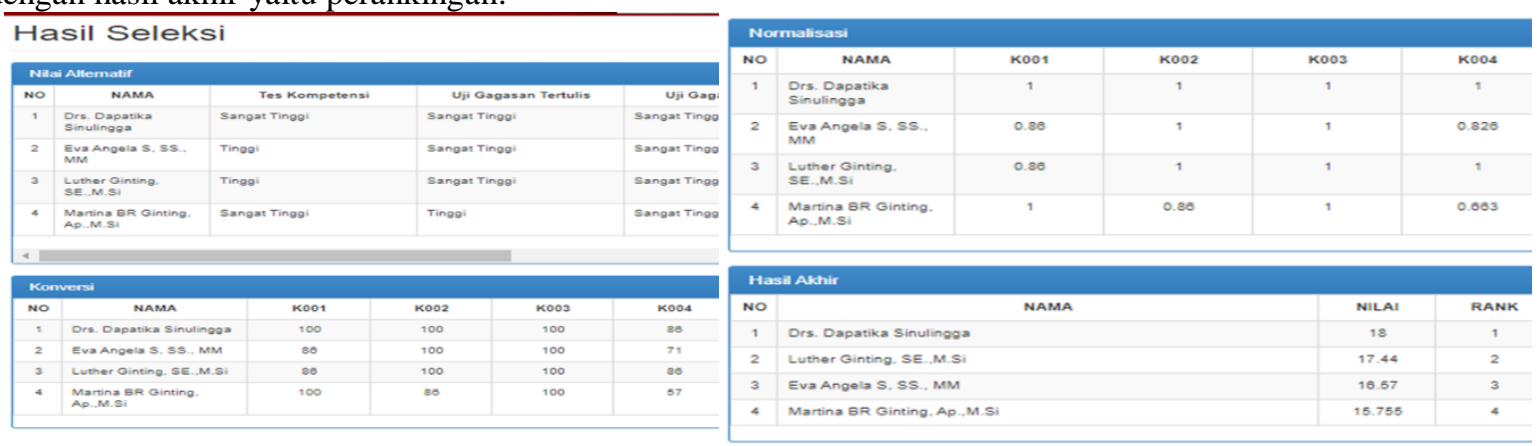

Gambar 5. Tampilan Hasil Seleksi

\section{Kesimpulan}

Kesimpulan dari penelitian : 
1. Sistem yang dibangun berbasis web namun tidak memiliki domain dan hosting.

2. Tidak dapat melakukan cetak terhadap hasil dari Pendukung Keputusan.

3. Tidak memiliki historyterhadap pendukung keputusan sebelumnya.

4. Peserta Tidak Memiliki Hak Akses untuk masuk kedalam sistem.

\section{Daftar Pustaka}

[1] S. Penunjang and K. Untuk, "Sistem penunjang keputusan untuk menentukan prioritas potensi desa menggunakan metode saw," J. Ilmu Komput. dan Sist. Inf. Sist., pp. 8-13, 2014.

[2] Muhammad Solehan Maulana Ibrahim, “Analisa Hasil Implementasi Metode Promethee Dan Saw Untuk Seleksi Penerimaan Bantuan Beras Untuk Warga Miskin Di Desa Cangkring Kecmatan Jenggawah,” Sist. Pendukung Keputusan, vol. 53, no. 9, pp. 1689-1699, 2017, [Online]. Available: http://www.sachajournals.com/African-Journal-of-Social-

Sciences.php\%5Cnhttp://ezproxy.lib.ucalgary.ca/login?url=http://search.ebscohost.com/login.aspx?dire $\mathrm{ct}=$ true $\& \mathrm{db}=\mathrm{ecn} \& \mathrm{AN}=1558385 \&$ site $=$ ehost live\%0Ahttp://www.ncbi.nlm.nih.gov/pubmed/27822349\%0Ahttp://www.

[3] D. Diana and I. Seprina, "Sistem Pendukung Keputusan untuk Menentukan Penerima Bantuan Sosial Menerapkan Weighted Product Method (WPM)," J. Edukasi dan Penelit. Inform., vol. 5, no. 3, p. 370, 2019, doi: 10.26418/jp.v5i3.34971.

[4] Nurul Putri Utami, Hasanul Fahmi, and Anita Sindar, "Spk Penentuan Pemberian Pinjaman Kepada Anggota Bumdes Dengan Metode Simple Additive Weighting," SINTECH (Science Inf. Technol. J., vol. 2, no. 2, pp. 124-130, 2019, doi: 10.31598/sintechjournal.v2i2.317.

[5] A. A. Azhari, Y. Nyura, and A. Najib, "Perbandingan Metode SAW dan TOPSIS Pada Penerimaan Siswa Praktek Kerja Lapangan,” Semin. Nas. Ilmu Komput. dan Teknol. Inf. 2018, vol. 3, no. 1, pp. 71-77, 2018.

[6] I. Mulyadin and D. S. Winarso, "Sistem Pendukung Keputusan Pemilihan Smartphone Menggunakan Metode Simple Additive Weighting," CAHAYAtech, vol. 7, no. 2, p. 88, 2019, doi: 10.47047/ct.v7i2.13.

[7] H. Hariyanto and S. Khotimah, "Sistem Pendukung Keputusan Pemilihan Supplier Terbaik Telur Bermerk Menggunakan Metode SAW Studi Kasus : PT. GIANT PONDOK KOPI," J I M P - J. Inform. Merdeka Pasuruan, vol. 3, no. 2, pp. 47-53, 2018, doi: 10.37438/jimp.v3i2.171.

[8] F. Sembiring, M. T. Fauzi, S. Khalifah, A. K. Khotimah, and Y. Rubiati, "Sistem Pendukung Keputusan Penerima Bantuan Covid 19 menggunakan Metode Simple Additive Weighting (SAW) (Studi Kasus : Desa Sundawenang)," Explor. Sist. Inf. dan Telemat., vol. 11, no. 2, p. 97, 2020, doi: 10.36448/jsit.v11i2.1563.

[9] P. Non et al., "Sistem Pendukung Keputusan Penerima Bantuan," vol. 17, no. 2, pp. 200-208, 2020.

[10] A. S. R. Sinaga and J. Purba, "Penentuan Karyawan Lembur Dengan Metode Analytical Hierarchy Process ( Ahp ),” vol. 1, no. 2, pp. 40-50, 2018. 